\title{
TERAPI NUTRISI PADA KARSINOMA AMELOBLASTIK DENGAN KEMOTERAPI
}

\author{
Rabiah, $^{1}$ Agussalim Bukhari ${ }^{2}$, Citra Kesumasari ${ }^{3}$, Asrini Safitri ${ }^{4}$ \\ ${ }^{1}$ Residen Ilmu Gizi Klinik, Fakultas Kedokteran Universitas Hasanuddin, Makassar - Indonesia \\ ${ }^{2,3,4}$ Departemen Ilmu Gizi, Fakultas Kedokteran Universitas Hasanuddin, Makassar - Indonesia \\ *Corresponding author, contact : rabiah20021985@gmail.com
}

\begin{abstract}
Ameloblastic carcinoma is a very rare malignant tumor of the odontogenic epithelium, accounting for approximately $2 \%$ of odontogenic tumors. The main purpose of nutritional therapy in cancer patients is to maintain or improve nutritional status so as to minimize the occurrence of complications, increase the effectiveness of cancer therapy (surgery, chemotherapy, radiation), quality of life and patient survival. A 59-year-old man was consulted with a diagnosis of ameloblastic carcinoma and severe malnutrition (Subjective Global Assessment Score C). The patient has a history of inadequate intake and changes in the consistency of intake for 4 months and has worsened in the last 10 days due to dysphagia. Pre-chemotherapy nutrition therapy is given with a target of $1900 \mathrm{kcal}$ gradually through enteral and parenteral with a protein of 1.5 grams/kg ideal body weight/day. Supplementations administered are zinc, vitamin B complex, vitamin $\mathrm{C}$, vitamin $\mathrm{D}$, curcuma and omega 3 . At the end of the treatment period there were metabolic improvements such as depletion of the immune system, albumin and nitrogen balance. The nutritional theraphy in ameloblastic carsinoma with adequate macronutrients and micronutrients fulfillment and immunonutrition is very important to improve nutritional status and immune disfunction.
\end{abstract}

Keywords : ameloblastic carcinoma, malnutrition, hypoalbuminemia

\begin{abstract}
Abstrak
Karsinoma ameloblastik adalah tumor ganas epitel odontogenik yang sangat jarang terjadi, terhitung sekitar $2 \%$ dari tumor odontogenik. Tujuan utama terapi nutrisi pada penderita kanker adalah untuk mempertahankan atau meningkatkan status gizi sehingga dapat memperkecil terjadinya komplikasi, meningkatkan efektivitas terapi kanker (bedah, kemoterapi, radiasi), kualitas hidup dan survival penderita. Pria usia 59 tahun dikonsulkan dengan diagnosis karsinoma ameloblastik dan malnutrisi berat (Subjective Global Assesment Skor C). Pasien memiliki riwayat asupan yang kurang dan perubahan konsistensi asupan selama 4 bulan dan memberat 10 hari terakhir karena disfagia. Terapi nutrisi pre-kemoterapi diberikan dengan target $1900 \mathrm{kkal}$ secara bertahap melalui enteral dan parenteral dengan protein 1,5 gram $/ \mathrm{kgBB}$ ideal $/$ hari. Suplementasi yang diberikan adalah zinc, Vitamin B kompleks, Vitamin C, Vitamin D, curcuma dan omega 3. Pada akhir masa perawatan terdapat perbaikan metabolik seperti deplesi system imun,albumin dan keseimbangan nitrogen. Terapi nutrisi pada kanker ameloblastik dengan pemenuhan makronutrien dan mikronutrien yang memadai dan imunonutrisi sangat penting untuk meningkatkan status gizi dan perbaikan sistem imun.
\end{abstract}

Kata Kunci : karsinoma ameloblastik, malnutrisi, hipoalbuminemia. 


\section{Pendahuluan}

Karsinoma ameloblastik adalah tumor ganas odontogenik epitel yang langka dan terjadi pada tulang maksilofasial dengan predileksi yang jelas di rahang bawah. Karsinoma ameloblastik biasanya agresif dengan kerusakan jaringan lokal yang luas. Karsinoma ameloblastik adalah tumor ganas , dengan angka kejadian sekitar 2\% dari tumor odontogenik. ${ }^{1-2}$ Dalam beberapa kasus, sel epitel akan bertransformasi menjadi ganas dari ameloblastoma yang sudah ada atau dari kista odontogenik jinak. ${ }^{3}$

Penelitian yang dilakukan oleh Rizzitelli,dkk menyatakan bahwa insiden terjadinya karsinoma ameloblastik pada anak-anak dan orang dewasa muda adalah 0,84 per 10 juta orang / tahun; dewasa, 2,5 per 10 juta orang / tahun dan lansia, 4,4 per 10 juta orang / tahun, kejadian juga secara signifikan lebih tinggi pada populasi kulit hitam dibandingkan pada populasi kulit putih. Anak-anak dan dewasa memiliki 89\% kelangsungan hidup pada 10 tahun pertama setelah didiagnosa penyakit tersebut. Sebaliknya, lansia memiliki persentase hidup lebih rendah (60\%) dan rata-rata kelangsungan hidup lansia adalah 6,6 tahun. Selain itu, populasi lansia adalah 9,6 kali lebih mungkin meninggal dibandingkan populasi dewasa muda. ${ }^{4}$
Nutrisi merupakan bagian yang penting pada pelaksanaan kanker, baik pada pasien yang sedang menjalani terapi, pemulihan dari terapi, pada keadaan remisi maupun untuk mencegah kekambuhan. Status nutrisi pada pasien kanker diketahui berhubungan dengan respon terapi, prognosis dan kualitas hidup. Kurang lebih 30- $87 \%$ pasien kanker mengalami malnutrisi sebelum menjalani terapi. Insiden malnutrisi tersebut bervariasi tergantung pada asal kanker. Salah satu masalah nutrisi yang perlu mendapat perhatian pada pasien kanker adalah kaheksia. Malnutrisi yang biasa terjadi terlebih dahulu disebabkan karena komponen nutrisi yang asupan tidak sesuai anjuran. ${ }^{5}$

Dukungan nutrisi mencakup pemberian nutrisi lebih dari asupan makanan dengan suplementasi melalui oral, enteral dan nutrisi parenteral. Tujuan dari dukungan nutrisi adalah untuk memastikan pencapaian kebutuhan nutrisi individual. Nutrisi oral menggunakan diet dan suplemen spesial yang biasanya dianggap sebagai terapi lini pertama dalam menangani malnutrisi, namun beberapa individu mungkin membutuhkan nutrisi enteral atau parenteral ketika asupan oral menurun atau ketika pasien tidak mampu menelan (tidak aman). Nutrisi enteral biasanya lebih disukai saat fungsi gastrointestinal tidak terganggu, lebih 
mudah pemberian nutrisinya dan menjaga fungsi barier usus ${ }^{6}$.

\section{Laporan Kasus}

Seorang pria, 59 tahun, dikonsulkan dari Departemen Bedah Onkologi dengan diagnosa Karsinoma ameloblastik T4N1M1 stadium 4 Karnofsky 70\%. Asupan makan via oral berkurang sejak 4 bulan yang lalu dan memberat sejak 10 hari sebelum masuk Rumah Sakit karena selera makan menurun akibat kesulitan membuka mulut dan mengunyah dikarenakan terdapat benjolan di pipi kanan. Penurunan berat badan yang tidak diinginkan ada dalam 4 bulan terakhir, namun besarannya tidak diketahui secara pasti. Pasien memiliki riwayat merokok selama 40 tahun sebanyak 1 bungkus per hari dan sudah berhenti sejak 4 bulan yang lalu. Pasien memiliki riwayat konsumsi alkohol selama 40 tahun, konsumsi 1 botol/bulan dan berhenti sejak 6 tahun yang lalu. Pada riwayat makan, sejak 4 bulan yang lalu, asupan pasien hanya setengah porsi biasanya dan sejak 10 hari terakhir hanya 5 sendok makanan lunak tanpa lauk dan sayur, namun pasien mengkonsumsi susu.

Pada pemeriksaan fisik sebelum kemoterapi, didapatkan tanda vital dalam batas normal. Antropometri menunjukkan panjang badan pasien $168 \mathrm{~cm}$, lingkar lengan atas $20 \mathrm{~cm}$, berat badan taksiran berdasarkan lingkar lengan atas 46,5 $\mathrm{kg}$ dan berat badan ideal $61,2 \mathrm{~kg}$. Kekuatan genggaman tangan (handgrip strength 14,7 $\mathrm{kg}$ ). Pasien memiliki loss of cutaneous fat pada bagian dada, serta abdomen cekung, tulang-tulang tampak prominen dan terdapat wasting pada keempat ekstremitas.

Saat dikonsul, kondisi metabolic pasien yang bermaksna adalah anemia normositik normokromik (hemoglobin 11.2 gr/dL), deplesi ringan system imun (1400), hipoalbuminemia serum (3.4 gr/dL). Keseimbangan nitrogen pasien sebelum dilakukan kemoterapi -11.76 dengan kadar nitrogen urea urin sebesar 1 gram/24 jam. Histopatologi pada mandibula dekstra menunjukkan adanya karsinoma ameloblastik yang bermetastasis ke kelenjar getah bening. Pasien menjalani kemoterapi.

\section{Pembahasan}

Asupan yang tidak adekuat pada pasien ini karena adanya disfagia akibat adanya karsinoma ameloblastik (sesuai dengan histopatologi ) sehingga pasien sulit untuk membuka mulut dan mengunyah makanan. Hal ini mengakibatkan, pasien mengalami kesulitan untuk makan, makanan masih dapat masuk akan tetapi jumlahnya berkurang dan konsistensinya berubah dari makanan padat menjadi makanan lunak dan 
makanan cair. Penatalaksanaan gizi prekemoterapi dan post-kemoterapi dilakukan untuk optimalisasi kondisi pasien, dimana asupan makanan direncanakan via enteral maupun parenteral, perlahan-lahan secara bertahap sambil mengawasi gejala-gejala intoleransi pasien terhadap makanan yang diberikan, sampai target kebutuhan energi terkoreksi pasien tercapai. Sebelum pulang, pasien dan keluarganya sudah diberikan edukasi mengenai pemberian nutrisi melalui enteral, sehingga dapat diteruskan di rumah.

\section{Pemberian suplementasi} multivitamin dan mineral penting dalam perannya sebagai antioksidan dan kofaktor atau koenzim dalam rantai metabolisme zat gizi makro, selain efek antioksidan yang menangkal radikal bebas secara tidak langsung berefek pada perbaikan nafsu makan dan asupan. Pilihan pemberian makan pada pasien ini adalah diet enteral, namun saat pasien tidak dapat mentoleransi pemberian diet enteral, diet parenteral digunakan sebagai penyokong.

Anemia pada penyakit kronik sering terjadi. Hal ini karena adanya asupan yang berkurang sejak lama karena adanya penyakit tumor yang diderita sehingga telah terjadi proses inflamasi di dalam tubuh. Anemia penyakit kronik merupakan suatu akibat dari proses inflamasi yang terjadi yang menyebabkan defek pada pelepasan zat besi dalam jaringan ke plasma transferrin pool. Selain itu juga akibat lain dari inflamasi (dari penyakit kronik) adalah tidak efektifnya eritropoiesis serta pada beberapa kasus ditemukan gangguan turnover dari zat besi. ${ }^{7}$ Selain itu, anemia post-kemoterapi merupakan invasi dari sel-sel normal disekitar jaringan tumor sehingga menyebabkan kehilangan banyak darah, infiltasi sumsum tulang dengan gangguan eritropoeisis dan defisiensi zat besi akibat proses inflamasi. ${ }^{8}$

Tujuan penanganan anemia adalah meningkatkan dan mempertahankan produksi sel darah merah, salah satunya dengan suplemen nutrisi. Penanganan anemia pada pasien ini dimulai dengan menjamin nutrisi pasien melalui nutrisi enteral dan parenteral serta suplementasi vitamin sehingga terjadi perbaikan asupan makronutrien dan mikronutrien pasien, sehingga kadar hemoglobin tidak terjadi penurunan secara drastis, dimana hemoglobin awal 11,1 g/dl menjadi 10,7 $\mathrm{g} / \mathrm{dl}$ pada akhir perawatan.

Deplesi sistem imun dapat terjadi akibat adanya reaksi inflamasi oleh stress oksidatif sehingga terjadi pelepasan sitokin proinflamasi. Jumlah limfosit total (TLC) merupakan salah satu parameter untuk melihat nilai fungsi sistim imun sebagai salah satu penilaian dalam status gizi. ${ }^{9}$ 
Beberapa penelitian mengemukakan bahwa terjadinya limfopenia adalah factor prediktif reversible untuk perkembangan atau relaps tumor lebih dini dan penurunan kelangsungan hidup. Prognosis buruk pasien kanker ditunjukkan dengan nilai TLC < $1000 / \mu$ L. Penyebab terjadinya limfopenia beragam, hal ini bisa disebabkan oleh karena radioterapi, kemoterapi, stress berat dan malnutrisi. ${ }^{10}$

Hipoalbuminemia yang terjadi pada pasien karena asupan tidak adekuat, dan penggunaan sebagai protein fase akut. Dimana pada awalnya, kadar albumin 3,4 gr/dl kemudian naik menjadi 3,6 gr/dl dan di akhir perawatan menjadi 3,5 gr/dl. Terapi nutrisi yang diberikan adalah memberikan energi dan asupan protein sebesar 1,2 gr/kgBBI/hari kemudian dinaikkan menjadi $1,5 \mathrm{gr} / \mathrm{kgBBI} / \mathrm{hari}$.

Pada kanker, didapatkan laju sintesis dan turnover albumin akan meningkat akibat proses inflamasi yang terjadi. Inflamasi diketahui sebagai salah satu penyebab hipoalbuminemia. Pada inflamasi, sitokin seperti TNF- $\alpha$ dan IL-1 akan menstimulasi asam amino untuk sintesis sitokin inflamasi lain dan protein fase akut yang positif seperti globulin, fibrinogen, dan haptoglobin, sedangkan sintesis protein fase akut yang negatif seperti albumin akan menurun. Rerata penurunan kadar albumin selama proses inflamasi secara signifikan mencapai 0,5 g/dL. Selain itu, malnutrisi juga terkait dengan hipoalbuminemia. Sintesis albumin menurun sekitar 50\% setelah puasa 24 jam terutama akibat berkurangnya asupan protein $^{11}$.

Kombinasi dari kurangnya asupan nutrisi, terganggunya proses sintesis albumin (dapat diakibatkan kerusakan mRNA pembentuk albumin) serta tingginya katabolisme dalam tubuh (terutama protein), maka hal ini menghasilkan kondisi yaitu hipoalbumin. ${ }^{11}$ Tingginya katabolime pada pasien ini terlihat dengan adanya keseimbangan nitrogen -11,76 pada awal perawatan. Setelah 14 hari perawatan, keseimbangan nitrogen menjadi $+4,4$.

Inflamasi berperan dalam perkembangan kaheksia dan berpengaruh negatif terhadap survival pasien, sehingga penggunaan nutrien antiinflamasi penting untuk mengurangi sindrom kanker kakheksia. Intervensi nutrisi yang diberikan yaitu memenuhi kebutuhan nutrisi baik kebutuhan energi, makronutrien dan mikronutrien serta suplementasi antiinflamasi dan antioksidan. Pada pasien ini juga diberikan anti inflamasi berupa curcuma $400 \mathrm{mg}$ per 8 jam dan EPA $400 \mathrm{mg}$ per 8 jam untuk mengurangi proses inflamasi yang terjadi akibat kanker sehingga dapat meningkatkan sistem 
imunnya.

Pemberian supplementasi curcuma sebanyak 1,2 gram per hari terbagi dalam 3 dosis karena curcuma yang mengandung zat curcumin dalam beberapa penelitian yang telah dipublikasikan mempunyai aktifitas sebagai antiinflamasi, antioksidan dan sebagai appetite stimulant. Aktifitas sebagai anti inflamasi dengan bekerja melalui penekanan terhadap cyclooxygenase-2 (COX-2) dan lipooxygenase (LOX), dan menghambat produksi sitokin inflamasi seperti tumor necrosis factor alpha (TNF$\alpha$ ), interleukin (IL) $-1,-6$, Di samping itu kurkumin juga memperlihatkan efek sebagai penangkap radikal bebas. Curcuma dapat juga meningkatkan nafsu makan atau sebagai appetite stimulant. Curcumin juga dapat menghambat $\mathrm{NF} x \mathrm{~B}$ sehingga proteolisis yang biasanya terjadi pada inflamasi akan terhambat ${ }^{12}$.

Makanan mengandung EPA dan DHA, setelah diserap, dengan mudah dimasukkan ke dalam membran seluler. EPA dan DHA yang terikat membran dilepaskan oleh enzim fosfolipase A2 yang sama yang mengarah pada pembentukan eikosanoid anti-inflamasi dan mediator lipid pro-resolving (resolvins dan protectins), yang bertanggung jawab untuk menyelesaikan inflamasi. Selanjutnya, EPA secara langsung bersaing dengan enzim yang terlibat dalam metabolisme asam arakidonat, memberikan pegangan tambahan dalam mengendalikan inflamasi ${ }^{13}$.

Dari beberapa penelitian terbaru menunjukkan bahwa pemberian suplementasi asam lemak omega 3 dapat mengurangi penghancuran protein dengan mencegah penumpukan faktor nukleus $\kappa \mathrm{B}$ di nukleus/inti sel sehingga menghambat terjadinya penghancuran protein otot. ${ }^{14}$

\section{Kesimpulan dan Saran}

Intervensi nutrisi diberikan untuk memenuhi kebutuhan nutrisi baik kebutuhan energi, makronutrien dan mikronutrien serta suplementasi sebagai antiinflamasi dan antioksidan. Pada pasien ini juga diberikan anti inflamasi berupa curcuma $400 \mathrm{mg}$ per 8 jam dan EPA $400 \mathrm{mg}$ (omega 3) per 8 jam untuk mengurangi proses inflamasi yang terjadi akibat kanker sehingga dapat meningkatkan sistem imunnya. Dengan pemenuhan makronutrien dan mikronutrien dapat mendukung perbaikan metabolik dari karsinoma ameloblastik dalam kemoterapi, sehingga dapat mempertahankan atau meningkatkan status gizi dan memperkecil terjadinya komplikasi, meningkatkan efektifitas terapi kanker, diantaranya kemoterapi, kualitas hidup dan survival penderita. 


\section{References}

1. Neville, B. W., Damm, D. D., \& Allen, C. M. (2009). Odontogenic Cysts and Tumors. Diagnostic Surgical Pathology of the Head and Neck, 785-838. https://doi.org/10.1016/B978-1-4160-25894.00010-3

2. Deng, L., Wang, R., Yang, M., Li, W., \& Zou, L. (2019). Ameloblastic carcinoma: Clinicopathological analysis of 18 cases and a systematic review. Head and Neck, 41(12), 4191-4198.

https://doi.org/10.1002/hed.25926

3. Gunaratne, D. A., Coleman, H. G., Lim, L., \& Morgan, G. J. (2015). Ameloblastic carcinoma. American Journal of Case Reports, 16, 415-419. https://doi.org/10.12659/AJCR.893918

4. Rizzitelli, A., Smoll, N. R., Chae, M. P., Rozen, W. M., \& Hunter-Smith, D. J. (2015). Incidence and overall survival of malignant ameloblastoma. PLoS ONE, 10(2), 1-9. https://doi.org/10.1371/journal.pone.011778 $\underline{9}$

5. Marischa, dkk. (2017). Malnutrisi Pada Pasien Kanker. Jurnal Medula, 7(4), 107111.

6. Kurien M, Penny H, Sanders DS. Impact of direct drug delivery via gastric access devices. 2015;1-9.

7. Weiss G. Anemia of chronic disease. N Engl J Med. 2014;(June).

8. Bryer, E., \& Henry, D. (2018). Chemotherapy-induced anemia: etiology, pathophysiology, and implications for contemporary practice. International Journal of Clinical Transfusion Medicine, Volume 6, 21-31. https://doi.org/10.2147/ijctm.s187569

9. Gonzalez, H., Hagerling, C., \& Werb, Z. (2018). Roles of the immune system in cancer: From tumor initiation to metastatic progression. Genes and Development,32(19-20),1267-1284. https://doi.org/10.1101/GAD.314617.118

10. Rodríguez, D. M., Guerrero, M. E., Maldonado, B. M., Vollbracht, C., \& Herrera, S. A. (2017). Total lymphocyte count in cancer patients with lymphopenia treated with intravenous vitamin C: Results of an observational study. Translational Medicine Communications, 2(1), 1-8. https://doi.org/10.1186/s41231-017-0012-x

11. Nicholson JP, Wolmarans MR, Park GR. The role of albumin in critical illness. Br J Anaesth [Internet]. 2000;85(4):599-610. Available from: http://dx.doi.org/10.1093/bja/85.4.599

12. Chattopadhyay I, Biswas K, Bandyopadhyay U, Banerjee RK. Turmeric and curcumin: Biological actions and medicinal applications. 2015;(November 2003).

13. Hadi S, Kurniawan C, Budiono J. Review Eicosapentaenoic Acid as Adjuvant for Cachexia in Cancer' s Patients. 2015;1-6.

14. Sergiyivna D, Miguel P, Ravasco P. Clinical Nutrition ESPEN Should omega-3 fatty acids be used for adjuvant treatment of cancer cachexia? Clin Nutr ESPEN [Internet]. 2018;25:18-25. Available from: https://doi.org/10.1016/j.clnesp.2018.02.006 
Grafik Monitoring Asupan energi via enteral dan parenteral

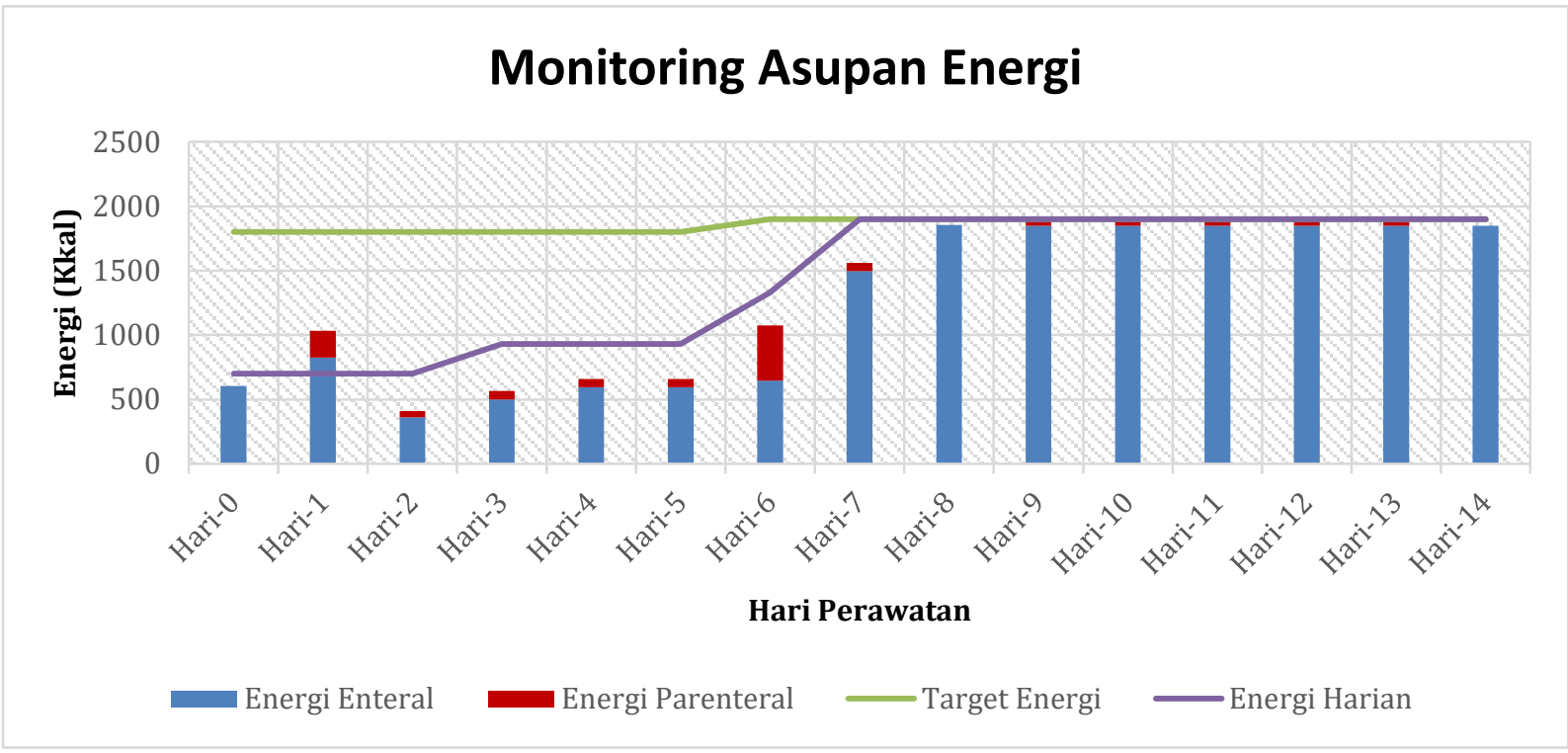

Grafik Monitoring Asupan Protein via enteral dan parenteral

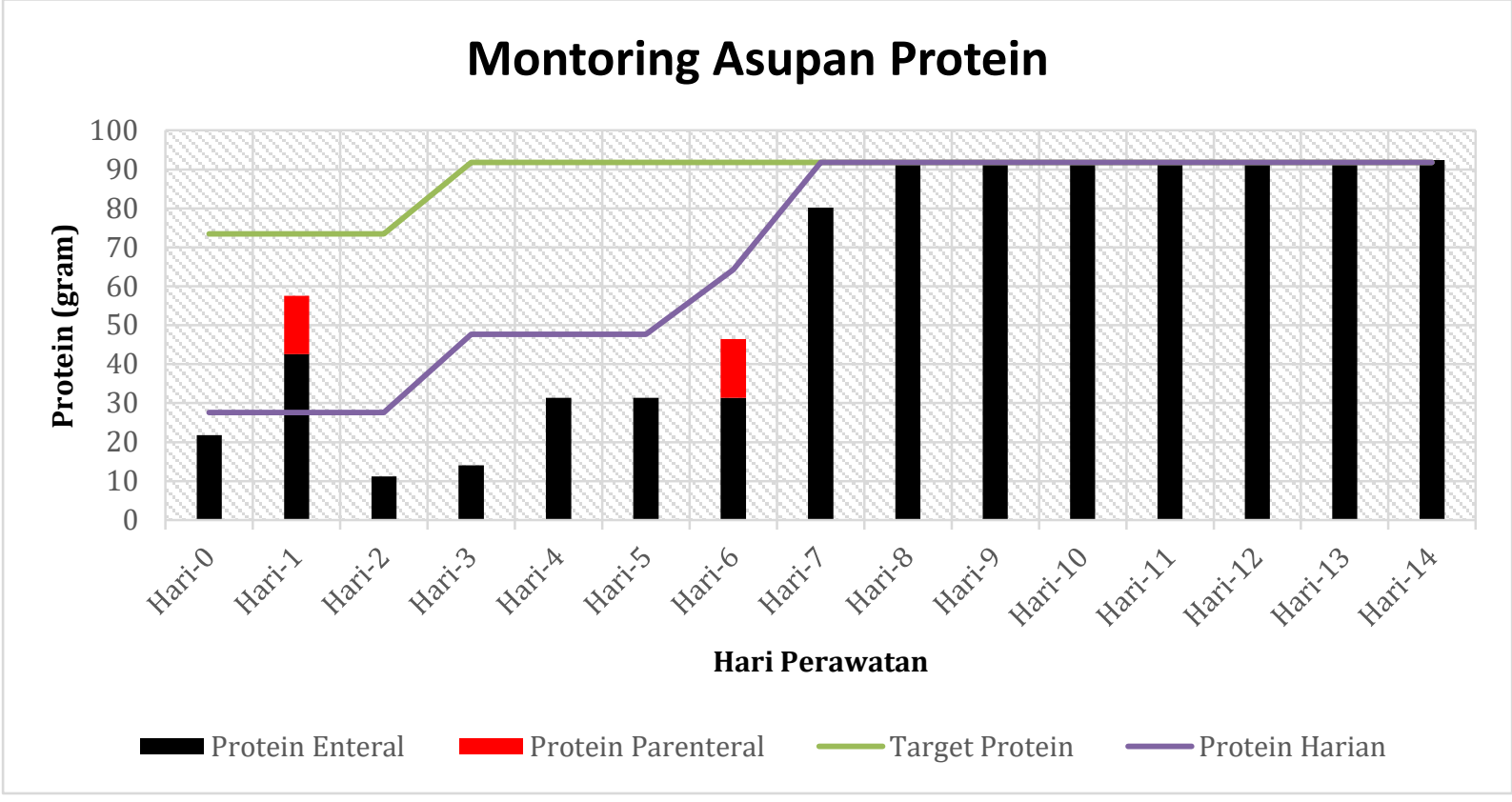


Grafik Monitoring Hemoglobin, Leukosit dan Total Limfosit Count

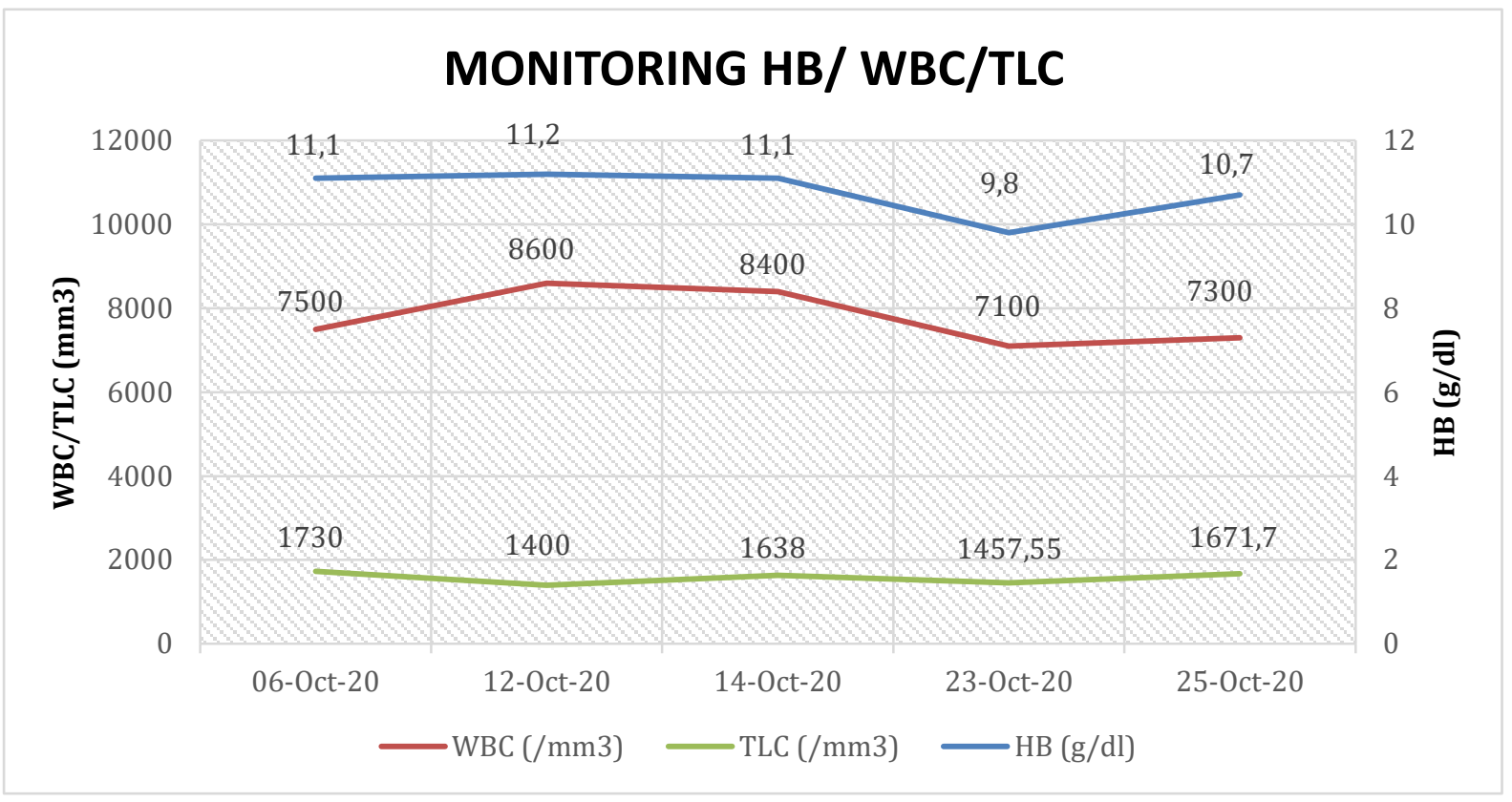

Grafik Monitoring Serum Albumin

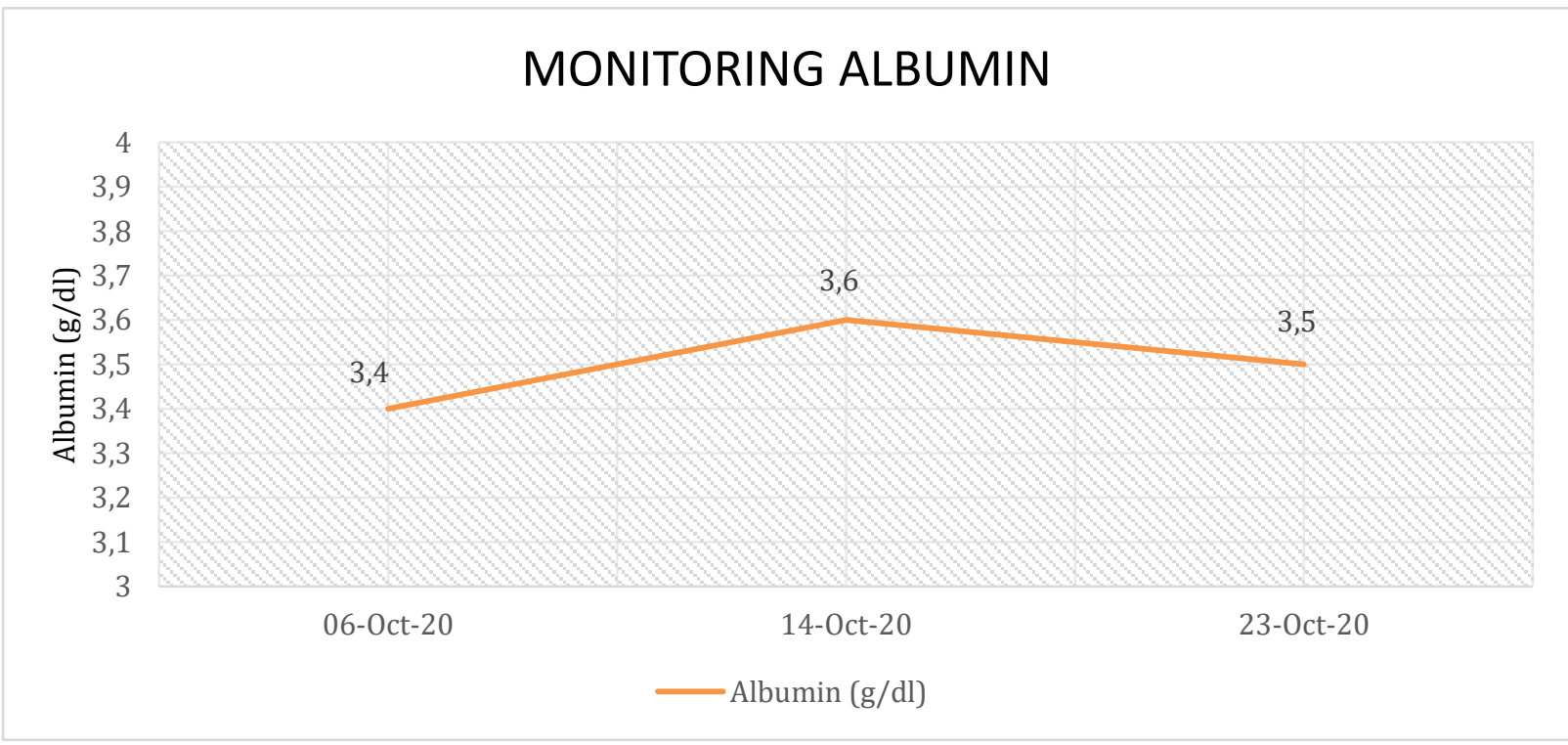


Grafik Monitoring Urine Urea Nitrogen (UUN) dan Keseimbangan Nitrogen

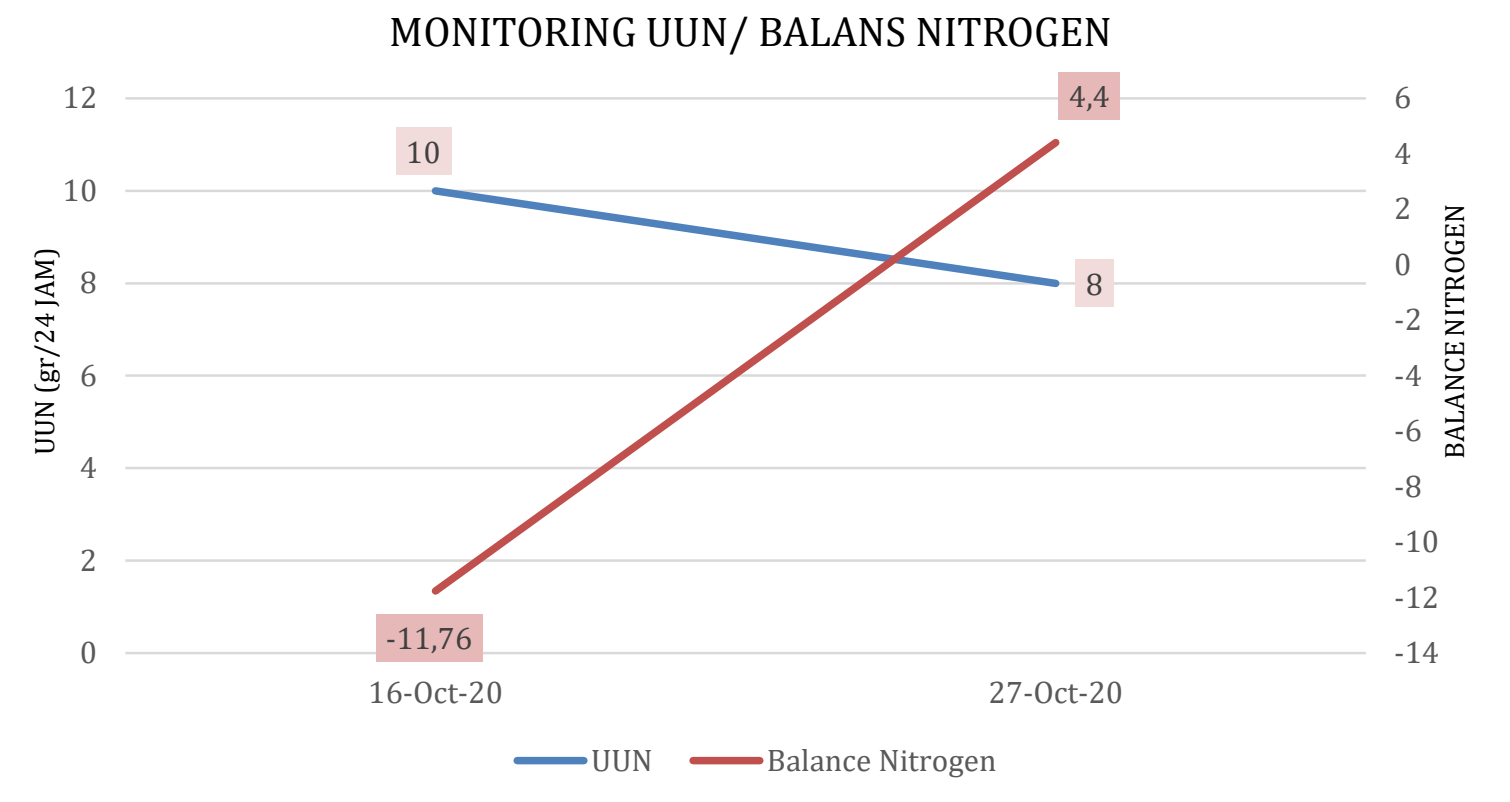

